\title{
In Search of Middle Indonesia
}




\title{
Verhandelingen van het Koninklijk Instituut voor Taal-, Land- en Volkenkunde
}

\author{
Edited by \\ Rosemarijn Hoefte \\ KITLV, Leiden \\ Henk Schulte Nordholt \\ KITLV, Leiden \\ Editorial Board \\ Michael Laffan \\ Princeton University \\ Adrian Vickers \\ Sydney University \\ Anna Tsing \\ University of California Santa Cruz
}

VOLUME 292

\section{Power and Place in Southeast Asia}

\author{
Edited by \\ Gerry van Klinken (KITLV) \\ Edward Aspinall (Australian National University)
}

VOLUME 4 


\section{In Search of Middle Indonesia}

Middle Classes in Provincial Towns

Edited by

Gerry van Klinken

Ward Berenschot

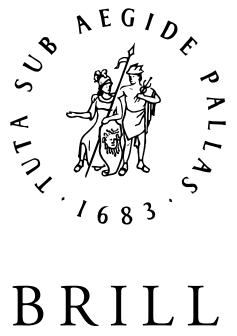

LEIDEN · BOSTON

2014 


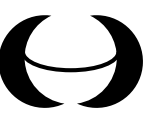

K I T L V

The realization of this publication was made possible by the support of KITLV (Royal Netherlands Institute of Southeast Asian and Caribbean Studies).

Cover illustration: TERNATE: An unguarded moment outside the market as evening falls. With the World Cup competition underway in South Africa, Ternateans went to considerable lengths to show support for their favourite teams, including complete re-decoration of their motorbikes — this one sports the Brazilian flag. As the matches played out in the middle of the night (local time), winning supporters paraded through the streets in such vehicles, waving giant flags.

June 2010: photo by S. Chris Brown.

\section{Library of Congress Cataloging-in-Publication Data}

In search of Middle Indonesia : middle classes in provincial towns / edited by Gerry van Klinken, Ward Berenschot. pages cm. -- (Verhandelingen van het Koninklijk Instituut voor Taal-, Land en Volkenkunde, ISSN 1572-1892 ; volume 292) (Power and place in Southeast Asia ; volume 4)

Includes bibliographical references and index.

ISBN 978-90-04-26300-0 (hardback : acid-free paper) -- ISBN 978-90-04-26343-7 (e-book) 1. Middle class-Indonesia. 2. City and town life--Indonesia. 3. Social classes--Indonesia. 4. Democracy--Social aspects-Indonesia. 5. Indonesia--Social conditions. 6. Indonesia--Economic conditions. I. Klinken, Geert Arend van. II. Berenschot, Ward.

HT69o.I5I5 2014

305.5'509598--dc23

2013040965

This publication has been typeset in the multilingual "Brill” typeface. With over 5,100 characters covering Latin, IPA, Greek, and Cyrillic, this typeface is especially suitable for use in the humanities. For more information, please see www.brill.com/brill-typeface.

ISSN 1572-1892

ISBN 978-90-04-26300-0 (hardback)

ISBN 978-90-04-26343-7 (e-book)

Copyright 2014 by the Editors and Authors, except for Sylvia Tidey's Chapter.

This work is published by Koninklijke Brill NV. Koninklijke Brill NV incorporates the imprints Brill, Brill Nijhoff, Global Oriental and Hotei Publishing.

Koninklijke Brill NV reserves the right to protect the publication against unauthorized use and to authorize dissemination by means of offprints, legitimate photocopies, microform editions, reprints, translations, and secondary information sources, such as abstracting and indexing services including databases. Requests for commercial re-use, use of parts of the publication, and/or translations must be addressed to Koninklijke Brill NV.

This book is printed on acid-free paper. 


\section{CONTENTS}

About the Authors ................................................................................................. vii

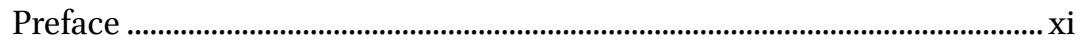

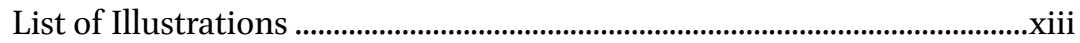

Introduction: Democracy, Markets and the Assertive Middle....................... 1

Gerry van Klinken

PART ONE

CLASS

Betting on the Middle? Middletown, Mojokuto and 'Middle Indonesia'.

Ben White

Working Class Revisited: Class Relations in Indonesian

Provincial Towns

Nicolaas Warouw

Class Mobil: Circulation of Children in the Making of

Middle Indonesia

Jan Newberry

\section{PART TWO}

THE STATE

A Divided Provincial Town: The Development from Ethnic to

Class-Based Segmentation in Kupang, West Timor.

Sylvia Tidey

Ethnicity and Young People's Work Aspirations in Pontianak

Wenty Marina Minza

Resisting Reforms: The Persistence of Patrimonialism in

Pekalongan's Construction Sector

Amalinda Savirani

PART THREE

EVERYDAY CULTURE

Growing up in Kupang

Cornelis Lay (with Gerry van Klinken) 
Between the Global and the Local: Negotiating Islam and Democracy in Provincial Indonesia 171 Noorhaidi Hasan

In Search of Middle Indonesian: Linguistic Dynamics in a

Provincial Town

Joseph Errington

Bibliography 221

Index. 239 


\section{ABOUT THE AUTHORS}

Ward Berenschot obtained his $\mathrm{PhD}$ (cum laude) in political science at the University of Amsterdam with a dissertation on Hindu-Muslim violence in India. This led to his book Riot politics (2011). He has taught and written on ethnic violence, local governance and access to justice. His current research focuses on local democracy, political clientelism and identity politics. He is a post-doctoral researcher at the KITLV, Leiden. berenschot@kitlv.nl

S. Chris Brown completed his $\mathrm{PhD}$ in anthropology at the University of Washington, Seattle, in 2009 ('Streets and Children in Surabaya'). One recent publication is the entry on Anjal in Figures of Southeast Asian modernity (Joshua Barker, Erik Harms, \& Johan Lindquist, eds., 2013). He prepared the Middle Indonesia photographic exhibition 'Sighting Middle Indonesia' currently on display at KITLV, Leiden.

seeingsubjects@gmail.com

Joseph Errington is professor of anthropology and member of the Council on Southeast Asian Studies at Yale University. He has done research on sociolinguistic change in Javanese and Indonesian. Recent publications include Linguistics in a colonial world (2008) and 'Indonesian among Indonesia's languages' in Producing Indonesia (ed. E. Tagliacozzo, in press).

j.errington@yale.edu

Noorhaidi Hasan is associate professor of Islam and politics at Sunan Kalijaga State Islamic University in Yogyakarta, where he is currently dean of the law school. Recent publications include Islam in the public sphere (co-edited by Irfan Abubakar, 2011); Islam politik di dunia kontemporer (2012); and 'Post-Islamist politics in Indonesia' in Post-Islamism (ed. Asef Bayat, 2013).

noorhaidi@hotmail.com

Gerry van Klinken is senior researcher at the KITLV and professor of Southeast Asian history at the University of Amsterdam. He coordinated the research programme In Search of Middle Indonesia. Recent 
sole-authored publications include The making of Middle Indonesia (2014) and Communal violence and democratization in Indonesia (2007). He now coordinates the multi-disciplinary research project Elite Network Shifts (computational network analysis on electronic news archives), and researches the history of citizenship practices in Indonesia.

klinken@kitlv.nl

Cornelis Lay teaches politics and government at Gadjah Mada University. He works on state-civil society relations, democratic governance and political parties in Indonesia. Among several coordinating roles, he is a leading member of the team developing the international research programme Power, Welfare and Democracy. Recent publications include 'Pancasila, Soekarno dan Orde Baru' (Prisma, 2013), and 'From populism to democratic polity' (with Pratikno) in Democratization in the global south (ed. Kristian Stokke and Olle Tornquist, 2013). He served as advisor to the fifth president of Indonesia, Megawati Soekarnoputri.

cornelislay@yahoo.com

Wenty Marina Minza lectures in psychology at Gadjah Mada University. She is also a researcher with the Center for Population and Policy Studies, and with the Center for Indigenous and Cultural Psychology at the same university. She is a PhD candidate at the University of Amsterdam. Her current research focuses on the indigenous psychology of interpersonal relationships among young people in Indonesia.

wm_minza@yahoo.com

Jan Newberry teaches anthropology at the University of Lethbridge, Alberta, Canada, where she currently chairs the department. Her book Back door Java (2006) appeared in Indonesian translation in 2013. Recent publications include 'Introduction to special forum on discovering, exploring and colonizing the realms of childhood' (with Elizabeth Galway and Louise Barrett, Jeunesse, 2012), 'Empowering children or disempowering women?' (Ethics and Social Welfare, 2012), and 'The global child and non-governmental governance of the family in post-Suharto Indonesia' (Economy and Society, 2010).

jan.newberry@uleth.ca

Amalinda Savirani is currently completing her $\mathrm{PhD}$ dissertation on the political behaviour of business actors in the provincial town of Pekalongan, Central Java, at the University of Amsterdam. She teaches politics at her 
alma mater Gadjah Mada University. She is interested in business-politics relations, states and markets, and development. She coordinates the Expert Survey on Democracy, part of the international research collaboration Power, Welfare and Democracy, 2010-2015, with the University of Oslo.

lindasavirani@yahoo.com

Sylvia Tidey obtained her PhD at the University of Amsterdam ('State, society and reciprocal obligations in Kupang, Eastern Indonesia', 2012). Recent publications include 'A divided provincial town' (City \& Society, 2012) and 'Corruption and adherence to rules in the construction sector' (American Anthropologist, 2013). She is currently a postdoctoral researcher on HIV/ Aids in Indonesia at the University of Amsterdam.

sylviatidey@hotmail.com

Nicolaas Warouw teaches Indonesian Studies at the University of New South Wales in Canberra, Australia. He previously taught anthropology at Gadjah Mada University. Recent publications include Democracy building on the sand (co-ed. with W.P. Samadhi, 2009) and 'Industrial workers in transition' in Women and work in Indonesian (eds. M. Ford and L. Parker, 2008).

n.warouw@adfa.edu.au

Ben White is emeritus professor of rural sociology at the International Institute of Social Studies, The Hague. He is co-editor of The new enclosures (2013) and of 'Growing up in Indonesia' (special issue, The Asia Pacific Journal of Anthropology, 2012).

white@iss.nl 
Gerry van Klinken and Ward Berenschot - 9789004263437 Downloaded from Brill.come4/26/2023 11:40:10AM via free access 


\section{PREFACE}

The collective writing effort that led to this book began with a brainstorming workshop at Gadjah Mada University in July 2005. We talked about the rapid social changes surrounding Indonesia's 1998 economic crisis, democratization, and decentralization. Previous work on the nation's local politics had made several of us aware of the mediated nature of these complex processes (Schulte Nordholt and Van Klinken 2007b; Van Klinken and Barker 2009; Aspinall and Van Klinken 2011). People in intermediate social and geographical locations influenced outcomes just by being able to pass on information and resources to others. Why had so little research been done on the middle classes in provincial towns who did much of this mediating work? we asked ourselves. We decided to put 'Middle Indonesia' on the research agenda.

In March 2007, most of the junior and senior researchers associated with the research programme 'In Search of Middle Indonesia' met for the first time in Leiden. Our host was the Royal Netherlands Institute of Southeast Asian and Caribbean Studies (KITLV), secretariat for the programme. We had been awarded generous funding by the Royal Netherlands Academy of Arts and Sciences (KNAW) under the second Scientific Program Indonesia-Netherlands (SPIN). KITLV also contributed research funding of its own.

Altogether 17 researchers joined in - five PhD candidates (one funded from outside), four postdoctoral research fellows who came to KITLV for a year or more, and eight postdoctoral fellows on shorter visits. About half came from Indonesia, the rest from all over the world. Three Dutch institutions participated in the consortium along with KITLV and Gadjah Mada: the University of Amsterdam, Leiden University, and the Institute of Social Studies (The Hague). Together with six senior supervisorresearchers, and a healthy number of outside friends, we enjoyed many workshops and conferences, in Indonesia and the Netherlands. If this volume has any merit, it is due to the unforgettable collegiality of those meetings. Of the many people who pushed us to sharpen our thinking, two deserve special mention. The Oxford University economist Barbara Harriss-White, whose work on Indian provincial towns had inspired many of us, was a stimulating presence at the conference in September 2010. And Henk Schulte Nordholt, research director at KITLV, was our most unstintingly loyal supporter and critic throughout. 
The present volume represents only a sample of the output the programme produced. Its authors were asked to explain what fresh light their empirical work shed on this extraordinarily productive yet poorly understood social zone we had called Middle Indonesia. We hope by this approach to stimulate others to focus on the exchanges taking place in the middle levels of this complex society.

As anyone who has done it can testify, producing a coherent edited volume is a time-consuming task. My colleague Ward Berenschot came to it after the Middle Indonesia researchers had gone home; yet he applied himself to his editorial task with energy and grace. All the authors and editors are grateful for two detailed and incisive anonymous reviewers reports obtained by the press. We thank S. Chris Brown for most of the photographs that grace this book. They show part of an exhibition commissioned by the programme and now hanging at KITLV. We also thank Klarijn Anderson-Loven, who went through the entire manuscript with an eagle's eye and prevented many errors and infelicities from reaching the printed page. Rosemarijn Hoefte, KITLV's liaison person at Brill, and Patricia Radder, senior editor at Brill, were unfailingly helpful throughout the publication process.

Gerry van Klinken (coordinator, In Search of Middle Indonesia research programme, 2005-2012) Leiden, July 2013 


\section{LIST OF ILLUSTRATIONS}

Map 1. The Indonesian Archipelago. Courtesy of KITLV, Leiden $\mathrm{XV}$

Fig. 1. TERNATE: Punk pals bask in the glow of friendship and the orange evening sky, in between running odd jobs for market vendors. June 2010: photo by S. Chris Brown xvi

Fig. 2. TERNATE: A fishmonger at the central market and bus terminal poses with her stock. She's fashionably outfitted against the midday sun with a broad hat and smears left by a thin rice-flour-and-turmeric paste applied earlier to protect her skin; alas, her fish boast no similar protection from the heat. June 2010: photo by S. Chris Brown

Fig. 3. KUPANG: Girl absorbed in a cell phone game while older kids play street soccer in downtown Kupang. Cell phones, with radios, games, music, cameras, and web access, are the new babysitters all over Indonesia. June 2010: photo by S. Chris Brown. .68

Fig. 4. TERNATE: This neighbourhood, once open to the cleansing action of the sea's tides, is becalmed by reclaimed land built further out by powerful developers. Hovering over the fetid bay like flyspecks, a dozen different national flags proclaim varied loyalties in the World Cup. June 2010: photo by S. Chris Brown

Fig. 5. PONTIANAK: A young woman working in an electronics shop is eager to pose for the camera. Too late, she is chagrined to realize that her mop will undermine the sophisticated air she hoped to project. June 2010: photo by S. Chris Brown

Fig. 6. TERNATE: Dock bosses spend much of the day (and night) at the central pier playing dominos for money, petty sums per point which can nevertheless add up to a tidy amount. Even though gambling is illegal, local police frequently join in the action. Meanwhile, more junior members of the dock gang are allocated actual loading and unloading of boats, from which the bosses reserve a cut. June 2010: photo by S. Chris Brown 
Fig. 7. PONTIANAK: The city is built on top of a swamp, with houses on stilts or piles; sometimes when a big truck passes by, you can almost see the asphalt ripple like a wave under its tires (and you can definitely feel the hollow reverberations). In some neighbourhoods the only dry land is the cemetery, which therefore doubles as a playground. May 2010: photo by

S. Chris Brown. 146

Fig. 8. PONTIANAK: An elementary teacher helps a forlorn student, waiting outside the schoolyard, arrange for a ride home. June 2010: photo by S. Chris Brown . 170

Fig. 9. KUPANG: Late at night, residents congregate at the edge of the main street near the mouth of their kampung. From this vantage they can sip tea, exchange jibes, and both monitor the comings and goings of their fellows while mingling themselves. August 2009: photo by S. Chris Brown. 


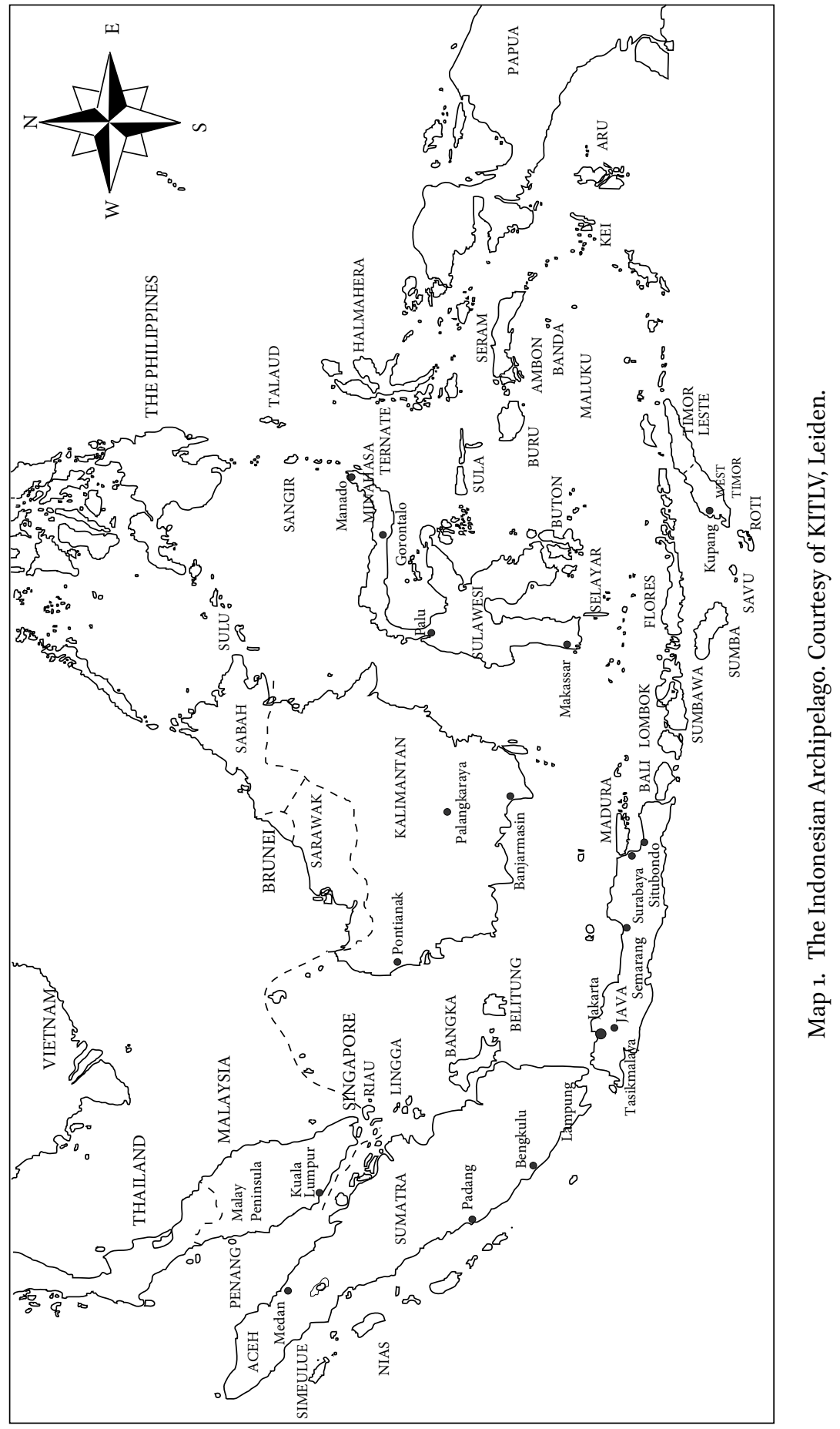

